\title{
Interest Rate Risk - A Comparative Study of Public and Private Sector Banks in India
}

\section{Reeta*}

Lovely School of Business, Lovely Professional University, India

\begin{abstract}
The Indian banks are exposed to so many risks like interest rate risk, liquidity risk, credit risk and exchange rate risk which affect the net interest income and profitability of the banks. This paper is aimed at measuring interest rate risk in public and private sector banks in India with the help of gap analysis. It is also found whether there is any difference in the level of interest rate risk in the selected public and private sector banks of India. The findings revealed that both the private sector banks and public sector banks are exposed to interest rate risk.
\end{abstract}

Keywords: Private sector banks; Public sector banks; Gap analysis; Assets-Liability mismatch

\section{Introduction}

These days, The Indian Economy is going to be a world class economy. The Indian banking industry is one of the most important parameter of the Indian economy which is also adopting new advancements in terms of technology, diversification and expansion. But it is also true that this sector is exposed to so many risks and interest rate risk is one of them. Financial transactions are fraught with ample risk not only because of changes in exchange rates but because of changes in interest rates also. With growing preference for floating interest rates since 1980s, the interest rate risk or exposure has become more significant. Interest rate risk is the risk to earnings or capital arising from movements in interest rates. Sometimes it moves in the favour of the lender, but then the debt burden of the borrower gets bigger. When it moves in the favour of the borrower, the lender has to suffer loss on account of interest. So in banking sector interest rate risk is considered the most important area which affects earnings and liquidity in banks. So it is necessary for the management of the bank to focus on the methods to measure this risk accurately and then do sound efforts to mitigate this risk.

\section{Literature Review}

Carter David A examines that interest rate derivatives can be used to mitigate the exposure of interest rate risk in banks [1]. He measured the level of interest rate risk by considering the absolute value of the 12 -months maturity gap analysis. Dhanani A determined various factors like interest rate fluctuations, use of borrowed funds etc. due to which interest rate risk arise [2]. He found that UK companies should hedge their interest rate risk to manage volatility in their profit and cash flows. Shashi Srivastava measured interest rate risk in SBI and ICICI bank and found that SBI is more exposed to interest rate risk as compared to ICICI bank [3]. He analyzed interest rate exposure by using various methods like assets-liability mismatch, gap analysis and sensitivity anlaysis and suggested to use interest rate derivatives to hedge this risk. Reeta analysed the measurement and management tools of interest rate risk used in Indian firms [4]. She found that interest rate risk is considered the most important risk in Indian firms and maximum firms use gap analysis and Maclay's Duration analysis to measure the level of interest rate risk. She also discussed various factors like monetary policy, inflation rate and fluctuations in money market which are responsible for interest rate changes.

VN Prakash Sharma examined the effect of interest rate changes on net interest income and on profitability of the Bank of Baroda and ICICI bank [5]. She used earning sensitivity analysis, duration gap analysis and rate adjusted gap to measure the level of interest rate risk.

\section{Objectives of the Study}

* To discuss the importance of interest rate risk in Indian Banks

* To compare the level of interest rate risk using Gap Analysis in selected public and private sector banks.

\section{Research hypothesis}

$\mathrm{H}_{0}$ There is no significant difference in the level of interest rate risk in public and private sector banks in India.

$\mathrm{H}_{1}$ There is significant difference in the level of interest rate risk in public and private sector banks in India.

\section{Research Methodology}

The study is analytical in nature. In this paper efforts are done to find out the prevailing level of interest rate risk in the Indian banks. For analysis top 5 banks are selected from public sector as well as from private sector on the basis of sales maximization and value of assets. The study is based on secondary data which has been collected from Indian Banking Association(IBA), Reserve Bank of India, moneycontrol.com, annual reports of the banks and Capita-line Plus database. Data is compiled for the financial year 2011-2015. Assets-Liability Mismatch and Gap analysis have been done to measure interest rate risk. Independent $\mathrm{t}$-test has been used to evaluate the significance of results. SPSS and MS-Excel are used for analysis [6].

\section{Analysis and interpretation}

Asset- liability management: For banks and financial institutions assets and liabilities are most important factors which get affected

*Corresponding author: Reeta, Assistant Professor, Lovely School of Business, Lovely Professional University, Phagwara, Punjab 144411, India, Tel: 09876722012 9992258210; E-mail: reeta.clonia@gmail.com

Received July 14, 2016; Accepted September 22, 2016; Published October 02 2016

Citation: Reeta (2016) Interest Rate Risk - A Comparative Study of Public and Private Sector Banks in India. J Bus Fin Aff 5: 212. doi: 10.4172/2167-0234.1000212

Copyright: @ 2016 Reeta. This is an open-access article distributed under the terms of the Creative Commons Attribution License, which permits unrestricted use, distribution, and reproduction in any medium, provided the original author and source are credited. 
because of interest rate changes. So doing proper match of assets and liabilities are advisable to mitigate the effect of interest rate changes. In the balance sheet of banks balances with banks and money at call, investment and advances are given at the assets side and in liabilities side deposits and borrowing are shown. When interest rate rises, it will affect both the assets as well as the liabilities. Now what will be the overall impact of this interest rate rise it depends on the total amount of assets and liabilities which a bank has? If interest rate sensitive assets of a bank are more as compared to interest rate liabilities then this interest rate changes will be beneficial for the concerned bank and vice versa. Here in the Table 1 interest rate sensitive assets and interest rate sensitive liabilities are shown of the selected private and public sector banks. The researcher compared the Rate Sensitive Assets (RSA) and Rate Sensitive Liabilities (RSL) of private sector banks with the public sector banks and found gap analysis which is shown with the help of Figure 1. Mean value of RSA and RSL are calculated for the financial year 2011-15 to evaluate the overall gap of public and private sector banks. Table 1 and Figure 1 show that except Bank of India (Rs. -1813 cr.) all selected banks have RSA $>$ RSL, it means they all have positive Gap and any changes in interest rate will positively affect the banks' net interest income and profitability [7]. But in case of Bank of India profitability will be affected negatively due to any changes in interest rates so it has to use some hedging techniques to mitigate interest rate exposure. In public sector banks SBI has the highest gap i.e. Rs. 607680 cr. and in case of private sector banks ICICI bank has the highest gap of Rs. 428111 cr (Table 1 and Figure 1).
Table 2 shows year wise gap analysis of each selected bank for the period of 2011 to 2015 and it shows the fluctuations of assets and liabilities throughout the research period. This table depicted that on an average all the banks either private or public (except Bank of India) have positive gap in maximum years. In 2011 three public sector banks (Punjab National Bank, Canara Bank and Bank of India) have negative value of gap. In case of private sector banks not even a single bank has negative gap in any year which is a symbol of appropriate assetsliability management.

Descriptive statistics and hypothesis testing: This paper is aimed to compare the level of interest rate risk using gap analysis in private and public sector banks so mean and standard deviation are calculated of public and private sector banks using SPSS which is shown in the Table 3. Here it shows that there is a difference in the mean value and the standard deviation of private and public sector banks. To check the homogeneity of variances of public and private sector banks Levene's test has been used and to check the significance of the mean difference independent $t$-test has been applied with the help of SPSS. Table 4 depicts that significance value under Levene's test is $0.591>0.05$ so $\mathrm{t}$-test assuming equal variance is applicable here. Result of $\mathrm{t}$-test using equal variance shows that $t$ statistics of 0.209 (Sig. $0.840>0.05$ ) indicate that there is no significant difference in the level of interest rate risk in private and public sector banks which means that the interest rate risk is the most important risk for public and private sector banks and both the sector are doing proper assets-liability management to make their

\begin{tabular}{|c|c|c|c|c|c|c|c|c|c|c|}
\hline \multicolumn{8}{|c|}{ Interest Rate Sensitive Assets and Liabilities (Mean Value computed in Crores for Financial Years from 2011-2015) } \\
\hline AssetsIBanks & ICICI & HDFC & AXIS & KM $^{*}$ & INDUSIND & SBI & PNB & CB $^{*}$ & BOI $^{*}$ & BOB $^{*}$ \\
\hline $\begin{array}{c}\text { Balances with Banks } \\
\text { and money at Call+ }\end{array}$ & 175351 & 92453 & 87748 & 15657 & 33806 & 454254 & 160361 & 175461 & 319327 & 765286 \\
\hline Investments + & 1658483 & 1134874 & 1049625 & 246935 & 188399 & 3705005 & 1285659 & 1158001 & 1002368 & 1028864 \\
\hline Advances + & 2973135 & 2527237 & 2040566 & 472132 & 458881 & 10359540 & 3148962 & 2634075 & 3048112 & 3338621 \\
\hline Total RSA & 4806969 & 3754564 & 3177939 & 734723 & 681085 & 14518799 & 4594982 & 3967538 & 4369807 & 5132771 \\
\hline Liabilities & & & & & & & & & & \\
\hline Deposits+ & 2934384 & 3139346 & 2530684 & 505518 & 530961 & 12303043 & 4073645 & 3741819 & 4015644 & 4701296 \\
\hline Borrowings + & 1444474 & 311799 & 468680 & 147551 & 118094 & 1608077 & 404360 & 205945 & 355976 & 289075 \\
\hline Total RSL & 4378858 & 3451145 & 2999364 & 653069 & 649055 & 13911120 & 4478005 & 3947764 & 4371620 & 4990371 \\
\hline GAP (RSA-RSL) & 428111 & 303419 & 178575 & 81654 & 32030 & 607680 & 116977 & 19774 & -1813 & 142401 \\
\hline
\end{tabular}

Source: Capita-Line Data Base, Calculation done by Author

*KM: Kotak Mahindra Bank, CB: Canara Bank, BOI: Bank of India, BOB: Bank of Baroda

Table 1: Assets-Liability Mismatch between private and public banks.

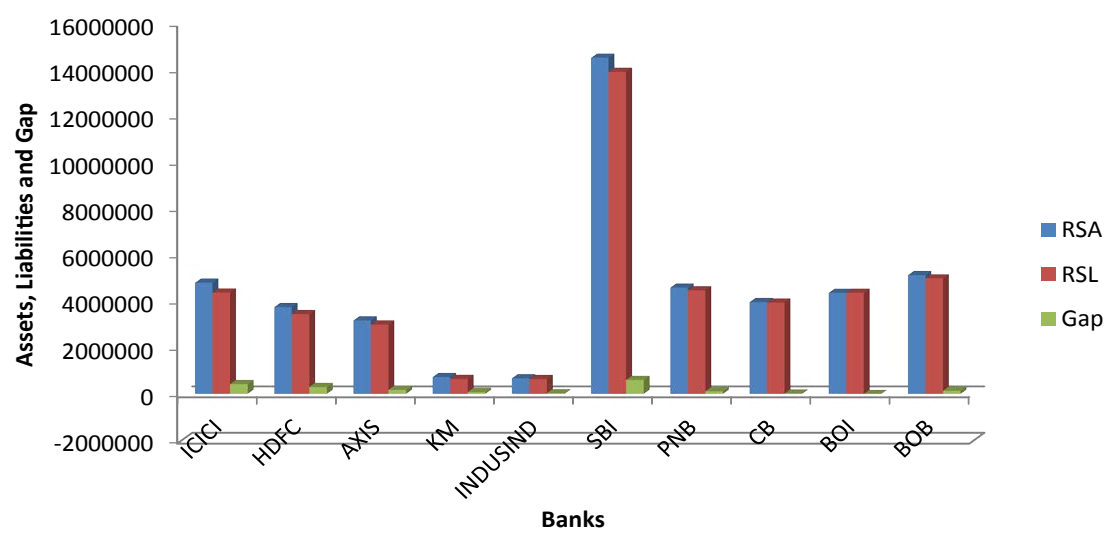

Figure 1: RSA, RSL and gap analysis of private and public banks. 
Citation: Reeta (2016) Interest Rate Risk - A Comparative Study of Public and Private Sector Banks in India. J Bus Fin Aff 5: 212. doi: 10.4172/21670234.1000212

Page 3 of 3

\begin{tabular}{|c|c|c|c|c|c|c|}
\hline \multicolumn{7}{|c|}{ Bank Wise Annual GAP Analysis in crores } \\
\hline BankslYear & 2015 & 2014 & 2013 & 2012 & 2011 & Average \\
\hline $\mathrm{ICICl}$ & 567737.3 & 487595.3 & 460527.1 & 333908.5 & 290785.8 & 428111 \\
\hline HDFC & 447667.8 & 314128.8 & 347334.3 & 282966.2 & 124995.8 & 303419 \\
\hline AXIS & 275058.4 & 235770.7 & 197816.8 & 120066.5 & 64162.6 & 178575 \\
\hline KOTAK MAHINDRA & 119058.4 & 95759.3 & 73842.8 & 61320.6 & 58290.9 & 81654.4 \\
\hline INDUSIND BANK & 56391.5 & 37560.7 & 39973.9 & 12283.8 & 13942.3 & 32030.4 \\
\hline STATE BANK OF INDIA & 720877.1 & 786828.8 & 735615.3 & 522107.9 & 272968.9 & 607680 \\
\hline PUNJAB NATIONAL BANK & 164768 & 165963.3 & 167602.5 & 99601.7 & -13050.9 & 116977 \\
\hline CANARA BANK & 25391.6 & 26172.1 & 64788.6 & 23523.9 & -41006.5 & 19773.9 \\
\hline BANK OF INDIA & -9125.1 & 17932.7 & -3574.2 & 49812.2 & -64110.2 & -1812.9 \\
\hline BANK OF BARODA & 234256.1 & 196599.3 & 210636.9 & 46596.2 & 23915 & 142401 \\
\hline
\end{tabular}

Table 2: Bank Wise Gap Analysis for the period 2011-2015.

\begin{tabular}{|l|c|c|c|c|c|}
\hline & Banks & N & Mean & Std. Deviation & Std. Error Mean \\
\hline GAP & Private & 5 & 204758 & 162246 & 72558.7 \\
\hline & Public & 5 & 177004 & 248485 \\
\hline
\end{tabular}

Table 3: Group statistics.

\begin{tabular}{|c|c|c|c|c|c|c|c|c|}
\hline & & \multicolumn{2}{|c|}{ Levene's Test } & \multicolumn{5}{|c|}{ t-test for Equality of Means } \\
\hline & & $\mathbf{F}$ & Sig. & $\mathbf{t}$ & df & $\begin{array}{c}\text { Sig. } \\
\text { (2-tailed) }\end{array}$ & Mean Difference & $\begin{array}{l}\text { Std. Error } \\
\text { Difference }\end{array}$ \\
\hline \multirow[t]{2}{*}{ GAP } & $\begin{array}{l}\text { Equal Variances } \\
\text { Assumed }\end{array}$ & 0.312 & 0.591 & 0.209 & 8.000 & 0.840 & 27754.196 & 132716.6 \\
\hline & $\begin{array}{c}\text { Equal variances not } \\
\text { assumed }\end{array}$ & & & 0.209 & 6.886 & 0.840 & 27754.196 & 132716.6 \\
\hline
\end{tabular}

Table 4: Hypothesis testing using t-test.

gap value positive so the benefit of interest rate changes can be achieved and negative exposure can be hedged (Tables 3 and 4).

\section{Conclusion}

Hence on the basis of the analysis done above it can be said that both the banks either it is private sector or public sector have been facing interest rate risk during the research period of the study but on an average except Bank of India all the banks have done their assetsliability management very well and they have positive value of gap throughout the research period and this thing has been proved by t-test also which shows that there is no significant difference in the level of interest rate risk in both sector banks. By doing this assets-liability management banks will be able to mitigate interest rate exposure up to a large extent and when their RSA $>$ RSL they can always get benefit of interest rate changes in terms of increased net interest income which leads to increase liquidity and profitability of the banks.

\section{Research Implications and Future Work}

This study is helpful for the selected banks for research to evaluate their performance and to develop some other innovative techniques to measure and manage interest rate risk. This study will also provide help to govt. to evaluate public sector banks and to instruct the officials of the public sector banks (in this research Bank of India has negative gap) to focus on proper assets- liability management to convert negative gap into positive. This study is done at small level by selecting 5 sample banks from private sector and 5 sample banks from public sector, in future this research can be done at large level by selecting all the banks of private sectors and public sectors to get more specific results. The research period of the study also can be expended to do further research.

\section{References}

1. David CA, Sinkey JF (1998) The use of interest rate derivatives by end users: The case of large community banks. Journal of Financial Services Research 14: 17-34.

2. Dhanani A (2005) Interest Rate Risk Management - An Investigation into the Management of Interest Rate Risk in UK Companies. Research Executive summary Series published by CIMA 2: 1-7.

3. Srivastava S, Srivastava D (2015) Interest Rate Risk Management: A Comparative Study of State Bank of India and ICICI Bank. International Journal of Management and Social Sciences Research (IJMSSR) 4.

4. Reeta (2013) Measurement and Management strategies of Interest Rate RiskA Study in Indian Perspective. GGGI Management Review 1: 7-11.

5. Sharma VNP, Santhosh NG (2016) Interest Rate Risk Management: A Comparative Study of Bank of Baroda and ICICI Bank. IOSR Journal of Economics and Finance (IOSR-JEF) 7: 01-04.

6. Froot KA, Scharfstein DS, Stein JC (1994) A framework for risk management Harvard Business Review pp: 91-102.

7. Charumathi B (2008) Asset Liability Management in Indian Banking Industry - with special reference to Interest Rate Risk Management in ICICI Bank. Proceedings of the World Congress on Engineering, London, UK. 